\title{
Disease Response Assessment Test Code
}

National Cancer Institute

\section{Source}

National Cancer Institute. Disease Response Assessment Test Code. NCI Thesaurus.

Code C117405.

A character or string that represents the short code name of the disease response assessment. 